\title{
Privilege and allyship in nonprofit food justice organizations
}

COMMENTARY ON RACE AND

ETHNICITY IN FOOD SYSTEMS

\author{
Danny W. Tarng * \\ Rutgers University-Camden
}

Submitted July 7, 2015 / Published online September 17, 2015

Citation: Tarng, D. W. (2015). Privilege and allyship in nonprofit food justice organizations. Journal of Agriculture, Food Systems, and Community Development, 5(4), 173-177. http://dx.doi.org/10.5304/jafscd.2015.054.029

Copyright (C) 2015 by New Leaf Associates, Inc.

\begin{abstract}
Nonprofit urban agriculture organizations are a key component of the food justice movement in U.S. cities. As the movement grows, an increasing number of allies will perform community food work and take leadership roles in nonprofit food justice organizations. One key to the ongoing growth and success of the movement is how allies transform their privilege into empowerment at an organizational scale. This commentary provides insight on how certain organizational policies and practice can lead to better allyship.
\end{abstract}

\section{Keywords}

food justice, community food, food movement,

* Danny W. Tarng, Department of Public Policy and Administration, Rutgers University-Camden; 401 Cooper Street; Camden, New Jersey 08102 USA; danny.tarng@,rutgers.edu

\section{Note}

This commentary is based on the author's ongoing dissertation work. allyship, privilege, empowerment, organization theory, shared leadership, social movement, nonprofit organizations, professionalization, urban agriculture

While many highly visible, effective nonprofit members of underprivileged social groups, a great number of nonprofit food justice organizations are created, led, and staffed by allies. By definition, allies are individuals from dominant social groups who work "to end the system of oppression that gives them greater privilege and power based on their social-group membership" (Broido, 2000, p.3; see also: Washington \& Evans, 1991). When doing social justice work, allies must firmly grasp their own positionality and constantly engage in selfreflection in order to identify ways in which their biases and approaches may be leading to counterproductive efforts (K. E. Edwards, 2006). Allyship's built-in self-reflection on one's unearned privileges closely mirrors the practice of cultural humility, i.e., a "lifelong commitment to self- 
evaluation and critique, to redressing power imbalances... and to developing mutually beneficial and non-paternalistic partnerships with communities on behalf of individuals and defined populations" (Tervalon \& Murray-Garcia, 1998, p. 117). Of interest here is how ally-led or ally-heavy urban agriculture organizations in U.S. can pursue nonpaternalistic and mutually beneficial work.

Much of today's food justice ally work in U.S. cities is encouraging, although some of it is met with skepticism from academics, activists, and others within the food justice movement, including members of the social groups whom allies seek to support. Some of this skepticism deals with the whiteness of alternative food (Alkon, 2012; Guthman, 2008, 2011; Slocum, 2006), with particular emphasis on the lack of People of Color in organizational leadership positions (Slocum, 2006). Ally-led or ally-heavy organizations will always be fighting the perception that they are outsiders imposing their ideas on a local population. Even if an organization gains the formal support of a local community group or community leaders, there will always be other local community stakeholders who remain suspicious of the ally organization's presence. With increasing institutional support for food justice, especially in the form of new or bolstered academic programs and policy institutes focusing on critical food studies and social justice, there will be an even greater influx of individuals from privileged backgrounds seeking community food jobs. This influx of outsiders with formal credentials that designate them as "qualified" in their field of practice will lead to an increasing professionalization of community food work, which if left unchecked can lead to food justice nonprofits settling for more moderate political goals (Jenkins, 1998) and centralizing decision-making authority (B. Edwards, 1994). It is important, then, that we closely examine both the concept and practice of food justice allyship so that current and future allies can avoid causing unintentional harm and creating trajectories leading to further exclusion of the social groups they are trying to support.

To re-emphasize, privilege or the lack of it is what separates allies from members of social groups that allies seek to support. It is often said in the food justice community that allies must start by first "acknowledging their privileges." Yet there is a great disparity between allies being aware of their privileges and their nonprofit organizations operating in a manner consistent with said level of awareness. Newman and Lake (2006) explain this disparity from a systems perspective, noting that the neoliberal framework in which today's communitybased organizations function limits their potential for political militancy and also allows them to avoid accountability to the communities in which they operate. From an organizational behavior perspective, concepts such as mission drift (see Ebrahim, Battilana \& Mair, 2014; Jones, 2007; Weisbrod, 2004), autocratic decision-making processes, and groupthink (Janis, 1982; Nemeth \& Staw, 1989) are common explanations for why organizations might cause unintentional harm. While understanding that all of these explanations are very important, this commentary is focused on how allies can transform their privilege into empowerment through organizational policies and practice.

With respect to food justice, privilege is commonly discussed in terms of food access. For example, someone living in a middle class suburb has easier access to affordable, fresh, healthy, and culturally appropriate food than someone living in a poor urban area or remote rural town. When placed within the context of nonprofit organizations, however, privilege denotes control over resources. While there are several factors that determine a nonprofit's ability to thrive, the lifeblood of formal nonprofits consists primarily of financial, human and social capital. For allies to share and eventually relinquish access to these resources in a resourcescarce environment seems like a counterintuitive strategy, for on its face it is threatening to the survival of one's career and organization. My response to this concern is that it is important for allies to reclaim the initial spirit of communitybased organizations, that is, to shift accountability and stakeholdership from external funding institutions back to the community, to grow local leaders capable of accessing the necessary resources to build community, and to collaborate more effectively with other community-based organizations that share common goals. 
The two cases below document organizations ${ }^{1}$ that have taken steps toward transforming their privilege into empowerment; in the first case, the transformation has been in an intraorganizational manner, and in the second case has been in an interorganizational manner.

\section{Intraorganizational Empowerment: Organizational Policy and Structure} One ally-led community food work organization distributes the power of privilege by implementing horizontal organizational governance practices. More precisely, the organization devolves key decision-making authority over program implementation from upper levels of management to the relevant program staff. In this case it is particularly important to note that some program staff are members of the disenfranchised social group that the organization supports. This organizational practice provides valuable program management and leadership experience to people who might not otherwise have opportunities to lead others and make important decisions in a formal organizational setting. This practice might also be an important stepping-stone toward increased responsibilities, allowing for the development of higherlevel management skills that could transfer to other fields and enhance these individuals' social mobility and economic security. In the best-case scenario, this job experience leads to each individual's selfdetermination as a socially conscious, politically active, and productive member of society.

To institutionalize this empowerment strategy, boards and upper-level management together can formulate a vision and implement organizational policy that commits to the idea of homegrown succession, wherein the organization must (1) meet a quota of paid employees who come from within the community that the organization serves, and (2) train these employees to become leaders of the organization or leaders of new spin-off or partner organizations. Such a policy will both address the immediate need for living-wage jobs in a distressed community, as well as commit the organization to a future in which allies are willing to share authority

\footnotetext{
${ }^{1}$ Identifiers were removed to protect the identity of these organizations.
}

and allow homegrown leaders to more fully determine the trajectory of food and social justice work in their communities.

Critical to the success of this homegrown succession policy are some important factors. One of the most important is that an organization must have the organizational culture, structure, and capacity to accommodate shared leadership (see Pearce \& Conger, 2002). In an ideal situation, directorship is shared between multiple staff. Some executive-level decisions with major ramifications are made by consensus, while the power to make less important executive decisions are distributed among co-directors. To build towards this leadership model it is vital to find resources to invest into developing the managerial competency of staff. The organization must possess the savvy to sell to their funders the importance of building the organization from within, or else seek other sources of revenue that do not restrict the organization's restructuring and political activity. In regard to actual empowerment tactics, allies must acquaint their future co-leaders with the relevant philanthropic, nonprofit, and community-development worlds. For example, allies can engage their future co-leaders in the grant-writing process and encourage them to participate in settings where greater decisions about our food systems occur (e.g., on food policy councils, at city planning meetings, and at meetings with legislators).

\section{Interorganizational Empowerment: A Programmatic Approach}

The second organization acts as the city's one-stop shop for garden resources, but creates its most sustainable impact by developing the capacity of its gardeners to facilitate change in their own communities. Affiliated gardeners who demonstrate a certain level of competence in horticulture and express a serious interest in taking on greater responsibility in their communities can attend a training program that provides trainees with the necessary resources and horticultural and community-organizing skills to become community leaders. The aspects of this training program specific to community organizing include strategies on how to engage neighbors, build community support, and entrust others with leadership 
responsibilities. The training program also instructs its participants on some important financial management competencies such as identifying sources of funding, grant-writing, budgeting, planning, and reporting.

Many graduates of the program have gone on to build community gardens and lead their own gardening workshops, while some have started their own nonprofit organizations. One of these nonprofits has addressed serious public safety concerns in its neighborhood by organizing community patrols and utilizing an array of urban greening efforts, including community gardens, market gardens that employ youths, and vacant-lot clearing and maintenance projects. Another training program participant went on to transform her organization from a small youth-development program into a community food hub that now runs a farm (composed of multiple affiliated market gardens), farmers market, shared commercial kitchen space, and resource center for local neighborhood gardeners.

Underpinning these transformative approaches to community-building and food justice is the philosophy that professionalized nonprofit organizations should do things "with" and not "for" their communities (Skocpol, 2003). Instead of building the community gardens or completing the urban agriculture-related projects for others, this case organization provides the necessary resources and technical support for those communities to organize and build these projects themselves.

\section{Discussion}

The ally's position in the community becomes more genuine and less impeachable when they are actively sharing their control over resources with members of the social group they are supporting. It also helps both the perception of the food justice movement as well as its outlook if its leadership is more diverse. Ally-led organizations doing community food work will always face issues of perception from critics and be met with suspicion by members of local disenfranchised communities. Well informed allies already understand that their presence as outsiders in disenfranchised communities represents a threat of displacement. Real or not, these perceptions are damaging to a food justice movement that is already trending toward increased professionalization. Despite the highest levels of self-awareness and self-reflection, it will always be hard for a strong ally to recognize when he or she is becoming part of the problem.

Scholars should also to continue to critically re-examine the role of nonprofit organizations in the food justice movement altogether. The ways that nonprofit food justice organizations are being funded and hence operate are becoming more homogenous and coherent with the way nonprofit organizations in different social service arenas operate (see Hwang \& Powell, 2009). While there is ample evidence to suggest that nonprofits can induce policy change through practice in the manner of policy entrepreneurship, a compelling argument can be made that some of these policy innovations are neoliberal in nature and ultimately come at the expense of building social movements and making greater systems change (DeFilippis, Fisher, \& Shragge, 2010). This is not to suggest that nonprofits should pursue monumental social change completely at the expense of short-term poverty alleviation efforts. Instead, nonprofits could perhaps build more constituent mobilization efforts into their current work.

\section{References}

Alkon, A. H. (2012). Black, white, and green: Farmers markets, race, and the green economy. Athens and London: The University of Georgia Press.

Broido, E. M. (2000). The development of social justice allies during college: A phenomenological investigation. Journal of College Student Development, 41(1), 3-18.

DeFilippis, J., Fisher, R., \& Shragge, E. (2010). Contesting community: The limits and potential of local organizing. New Brunswick: Rutgers University Press.

Ebrahim, A., Battilana, J., \& Mair, J. (2014). The governance of social enterprises: Mission drift and accountability challenges in hybrid organizations. Research in Organizational Behavior, 34, 81-100. http://dx.doi.org/10.1016/j.riob.2014.09.001

Edwards, B. (1994). Semiformal organizational structure among social movement organizations: An analysis of the U.S. peace movement. Nonprofit and Voluntary Sector Quarterly, 23(4), 309-333. http://dx.doi.org/10.1177/089976409402300403 
Edwards, K. E. (2006). Aspiring social justice ally identity development: A conceptual model. Journal of Student Affairs Research and Practice, 43(4), 12351256. http://dx.doi.org/10.2202/1949-6605.1722

Guthman, J. (2008). Bringing good food to others: Investigating the subjects of alternative food practice. Cultural Geographies, 15(4), 431-447. http://dx.doi.org/10.1177/1474474008094315

Guthman, J. (2011). "If they only knew": The unbearable whiteness of alternative food. In A. H. Alkon \& J. Agyeman (Eds.), Cultivating food justice: Race, class, and sustainability (pp. 263-281). Cambridge, Massachusetts: The MIT Press.

Hwang, H., \& Powell, W. W. (2009). The rationalization of charity: The influences of professionalism in the nonprofit sector. Administrative Science Quarterly, 54(2), 268-298. http://dx.doi.org/10.2189/asqu.2009.54.2.268

Janis, I. L. (1982). Groupthink: Psychological studies of policy decisions and fiascos (2nd Ed.). Boston: HoughtonMifflin.

Jenkins, J. C. (1998). Channeling social protest: Foundation patronage of contemporary social movements. In W. W. Powell and E. S. Clemens (Eds.), Private action and the public good (pp. 206-216). New Haven, Connecticut: Yale University Press.

Jones, M. B. (2007). The multiple sources of mission drift. Nonprofit and Voluntary Sector Quarterly, 36(2), 299-307. http://dx.doi.org/10.1177/0899764007300385

Nemeth, C. J., \& Staw, B. M. (1989). The tradeoffs of social control and innovation in groups and organizations. Advances in Experimental Social Psychology, 22, 175-210. http://dx.doi.org/10.1016/S0065-2601(08)60308-1

Newman, K., \& Lake, R. W. (2006). Democracy, bureaucracy and difference in US community development politics since 1968. Progress in Human Geography, 30(1), 44-61. http://dx.doi.org/10.1191/0309132506ph590oa

Pearce, C. L., \& Conger, J. A. (2002). Shared leadership: Reframing the hows and whys of leadership. Thousand Oaks, California: SAGE.

Skocpol, T. (2003). Diminished democracy: From membership to management in American civic life. Norman: University of Oklahoma Press.

Slocum, R. (2006). Anti-racist practice and the work of community food organizations. Antipode, 38(2), 327-349. http://dx.doi.org/10.1111/j.14678330.2006.00582.x

Tervalon, M., \& Murray-Garcia, J. (1998). Cultural humility versus cultural competence: A critical distinction in defining physician training outcomes in multicultural education. Journal of Health Care for the Poor and Underserved, 9(2), 117-125. http://dx.doi.org/10.1353/hpu.2010.0233

Washington, J., \& Evans, N. J. (1991). Becoming an ally. In N. J. Evans \& V. A. Wall (Eds.), Beyond tolerance: Gays, lesbians and bisexuals on campus (pp. 195-204). Washington, D.C.: American College Personnel Association.

Weisbrod, B. A. (2004). The pitfalls of profits. Stanford Social Innovation Review, 2(3), 40-47. http://ssrn.com/abstract $=1850719$ 